\title{
40. SOME ISOTOPE RELATIONS IN BASALTS FROM DEEP SEA DRILLING PROJECT HOLES 417A, 417D, AND 418A
}

\author{
V. L. Rusinov, N. N. Pertsev, M. M. Arakeljanz, and L. P. Nosik, Institute of Geology of the Ore Deposits, \\ Petrography, Mineralogy, and Geochemistry of the Academy of Sciences of USSR, Moscow, USSR
}

\section{INTRODUCTION}

Isotope measurements include 11 determinations of $\mathrm{K}-\mathrm{Ar}$ age for basalts, 14 determinations of $\delta^{13} \mathrm{C}$ and $\delta^{18} \mathrm{O}$ for calcite, and six determinations of $\delta^{34} \mathrm{~S}$ for pyrite.

\section{SULFUR ISOTOPES}

The sulfur isotope composition is related to those of meteorites. All measured values of $\delta^{34} \mathrm{~S}$ (Table 1) are negative and vary from -0.130 to -0.689 per cent. Thus, the sulfur in the sulfides investigated is lighter than that in meteorites. This may be due to the relatively high value of $\mathrm{PO}_{2}$ according to the $\mathrm{PO}_{2}-p \mathrm{H}$ diagram of Ohmoto (1968). Assuming that the $p \mathrm{H}$ of the solution is near neutral during the pyrite formation, the $\mathrm{PO}_{2}$ value is proximal to the boundary of pyrite and hematite fields of stability. Possible limits of the $p \mathrm{H}$ values are approximately 4 to 6 .

Variations of $\delta^{34} \mathrm{~S}$ within one sample are not significant, but they are noticeable between different samples. Cubic pyrite crystals ( 0.5 to $1 \mathrm{~mm}$ in diameter) are enclosed in dark green smectite in some veins in the core from the lower part of Hole 417A. In this hole, alteration of basalts is the strongest and the oxidation process is very intense, especially in the upper part of the core. Iron hydroxides are common in the upper part of the core; pyrite occurs only in the lower portion, where hydroxides are not observed. Macroscopically, pyrite is rarely observed and always in association with green $\mathrm{Mg}$-rich smectite in veins and some vesicles. In other holes (417D, 418A), pyrite is observed in many places, but only under the microscope as disseminated grains and veinlets with calcite or smectite. Therefore, pyrite is one of the newly formed minerals during basalt alteration and its depositional environments (relatively high $\mathrm{PO}_{2}$ and nearly neutral $\left.p \mathrm{H}\right)$ are characteristic of the alteration as a whole.

\section{CARBON AND OXYGEN ISOTOPES}

The isotopic composition of $\mathrm{C}$ and $\mathrm{O}\left(\delta^{13} \mathrm{C}, \delta^{18} \mathrm{O}\right)$ is determined for calcite from veins and cavities in basalts (Table 2). The veins are as wide as 10 to $15 \mathrm{~mm}$ and are filled with white coarse-grained calcite. The quantity of calcite veins and cavities does not show any dependence with depth and is approximately the same for the three holes investigated.

The isotopic composition of $\mathrm{C}$ is related to the Chicago standard and the $\mathrm{O}$ composition is related to the SMOW standard. Values of $\delta^{13} \mathrm{C}$ are close to zero and shift slightly into the negative region (Figure 1). Values of $\delta^{18} \mathrm{O}$ are also close to zero but shift slightly in the positive region. The limits of values are $\delta^{13} \mathrm{C}=-0.5$ to +0.3 per cent, $\delta^{18} \mathrm{O}=$ -0.3 to +0.6 per cent. Fluctuation of the values has the
TABLE 1

Isotopic Composition of Sulfur
in Pyrite From Hole 417A
Samples

\begin{tabular}{cc}
\hline $\begin{array}{c}\text { Sample } \\
\text { (Interval in cm) }\end{array}$ & $\delta^{34} \mathrm{~S} \pm 0.01 \%$ \\
\hline $38-3,55-57$ & -0.206 \\
$44-1,10-11$ & -0.130 \\
$44-1,11-12$ & -0.176 \\
$44-2,90-93$ & -0.689 \\
$44-2,90-93$ & -0.664 \\
$44-3,80-82$ & -0.290 \\
\hline
\end{tabular}

TABLE 2

${ }_{8}^{13} \mathrm{C}$ and $\delta^{18} \mathrm{O}$ Values for Calcite From Holes 417A, 417D, and 418A

\begin{tabular}{lcc}
\hline $\begin{array}{c}\text { Sample } \\
\text { (Interval in cm) }\end{array}$ & ${ }^{13} \mathrm{C}$ & ${ }^{18} \mathrm{O}$ \\
\hline Hole 417A & & \\
28-2, 80-83 & -0.44 & 0 \\
$30-6,91-95$ & -0.28 & +0.25 \\
$36-4,30-34$ & -0.41 & -0.12 \\
$42-6,145-150$ & -0.06 & +0.59 \\
& & \\
Hole 417D & & \\
$29-1,0-5$ & +0.21 & 0 \\
$30-5,67-33$ & -0.06 & +0.46 \\
$30-8,68-76$ & -0.38 & -0.18 \\
$31-4,33-40$ & -0.16 & 0 \\
$33-4,122-124$ & -0.40 & 0 \\
& & \\
Hole 418A & & \\
$15-3,146-148$ & -0.30 & +0.28 \\
$26-2,125-127$ & -0.50 & -0.28 \\
$34-5,136-139$ & -0.30 & +0.10 \\
$35-4,62-64$ & +0.31 & +0.26 \\
$55-5,112-115$ & -0.20 & 0 \\
\hline
\end{tabular}

same meaning for both $\delta^{18} \mathrm{O}$ and $\delta^{13} \mathrm{C}$. There is no clear evidence for the dependence of these parameters with depth.

\section{K-Ar DETERMINATIONS}

$\mathrm{K}-\mathrm{Ar}$ age was determined in the Laboratory of Geochronology of the Institute of Geology of the Ore Deposits, Petrography, Mineralogy, and Geochemistry, Academy of Sciences of USSR. The analytical results are plotted in Table 3 and Figure 2.

The 10 to 15 mesh fraction of ground whole-rock samples was used. Potassium was determined by flame spectrophotometry. Argon analyses were made using isotope dilu- 


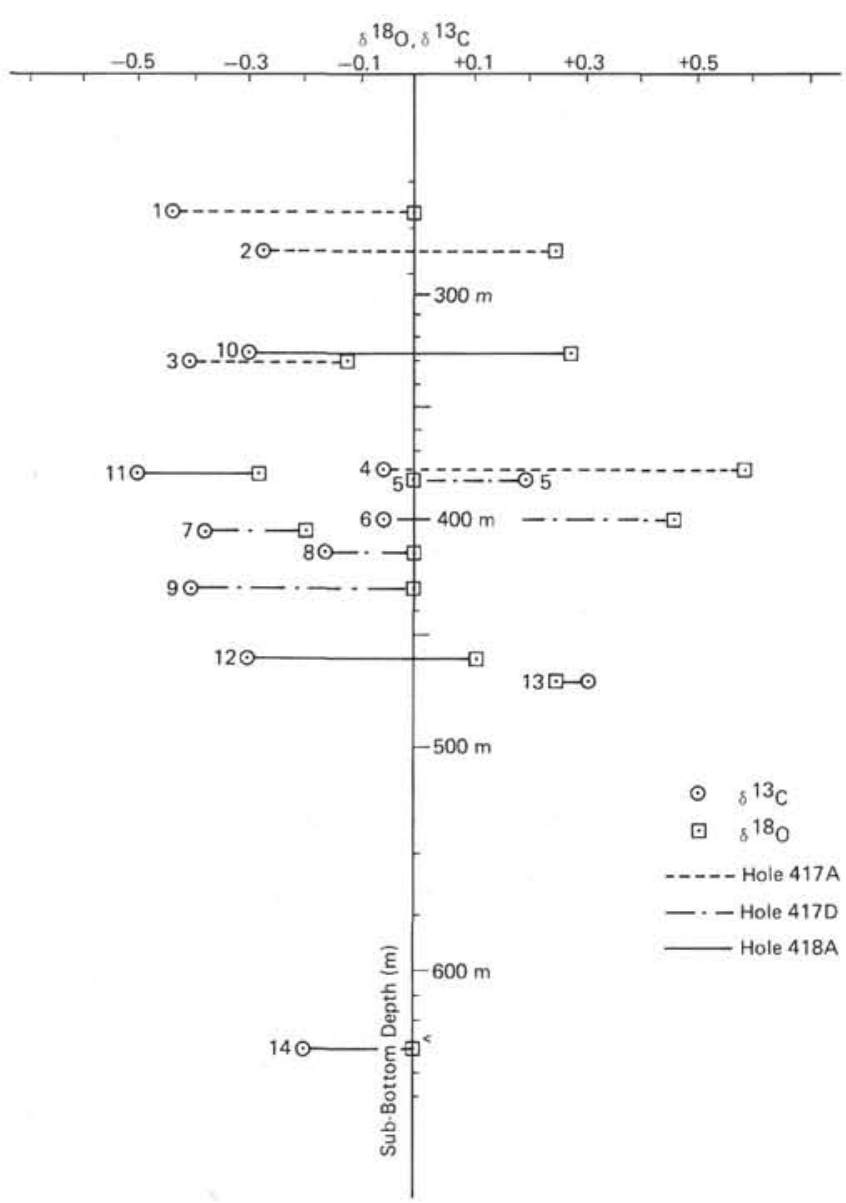

Figure 1. Values of the $\delta^{18} \mathrm{O}$ and $\delta^{13} \mathrm{C}$ versus depth for Holes $417 A, 417 D$, and $418 A$. Numbers correspond to those in Table 2.

tion techniques with an addition of an $\mathrm{Ar}^{38}$ tracer. The following ${ }^{40} \mathrm{~K}$ decay constants used were: $\lambda \mathrm{K}=0.581 \times 10^{-10}$ years $^{-1}, \lambda=4.962 \times 10^{-10}$ years $^{-1},{ }^{40} \mathrm{~K}=0.1167$ (atm. \%). These were accepted by the International Subgroup of Geochronology in 1976 during the XXV Session of the International Geologic Congress (Australia). The errors in $\mathrm{Ar}$ and $\mathrm{K}$ content are the mean value of the standard deviation at the 60 per cent confidence level. The error in age determination is the mean value of the deviation at the 90 per cent confidence level.

Resulting values lay within the interval of 60 to $111 \mathrm{~m} . \mathrm{y}$. (Table 3). An expected age of the basalts drilled was approximately 100 to $110 \mathrm{~m}$.y., because the age of magnetic anomaly $M O$ is $108 \mathrm{~m} . \mathrm{y}$. However, only in one sample $(418 \mathrm{~A}-37-1,28-32 \mathrm{~cm})$ is $\mathrm{K}-\mathrm{Ar}$ age of basalt greater than $100 \mathrm{~m} . \mathrm{y}$. Close to this value are two values of 90 and 91 m.y. from Holes 417D and 418A. Other measurements show significantly younger ages. The highest values mentioned above are associated with almost fresh or slightly to medium altered basalts, while the age of about $60 \mathrm{~m} . \mathrm{y}$. is typical for badly altered rocks with high $\mathrm{K}_{2} \mathrm{O}$ and $\left(\mathrm{Fe}_{2} \mathrm{O}_{3}: \mathrm{FeO}\right)$, low $\mathrm{CaO}$, and common $\mathrm{K}$-feldspars replacing plagioclase phenocrysts (Figure 2 ). This is the case with the
TABLE 3

K-Ar Age of Basalts From Holes 417A, 417D, and 418A

\begin{tabular}{|c|c|c|c|c|}
\hline \multirow[b]{2}{*}{$\begin{array}{c}\text { Sample } \\
\text { (Interval in } \mathrm{cm} \text { ) }\end{array}$} & \multicolumn{3}{|c|}{ Content } & \multirow[b]{2}{*}{ Age (m.y.) } \\
\hline & $\mathrm{K}(\%)$ & Radiog. Ar (ng/g) & $\sqrt{\frac{{ }^{40} \mathrm{Ar}_{\text {rad }}}{{ }^{40} \mathrm{Ar}_{\text {total }}}}$ & \\
\hline \multicolumn{5}{|l|}{ Hole 417A } \\
\hline $\begin{array}{l}26-5,75-78 \\
35-2,63-68\end{array}$ & $\begin{array}{l}3.19 \pm 0.03 \\
0.80 \pm 0.02\end{array}$ & $\begin{array}{r}13.4 \pm 0.5 \\
3.4 \pm 0.4\end{array}$ & $\begin{array}{l}54: 56 \\
35: 53\end{array}$ & $\begin{array}{l}60 \pm 3 \\
61 \pm 4\end{array}$ \\
\hline \multicolumn{5}{|l|}{ Hole 417D } \\
\hline $\begin{array}{l}22-4,51-55 \\
26-1,48-54 \\
26-1,54-62 \\
43-3,28-30\end{array}$ & $\begin{array}{l}0.26 \pm 0.03 \\
0.87 \pm 0.02 \\
0.49 \pm 0.02 \\
0.26 \pm 0.03\end{array}$ & $\begin{array}{l}1.2 \pm 0.2 \\
4.8 \pm 0.5 \\
2.3 \pm 0.2 \\
1.7 \pm 0.15\end{array}$ & $\begin{array}{l}10: 12 \\
37: 39 \\
10: 19 \\
11: 12\end{array}$ & $\begin{array}{l}65 \pm 10 \\
77 \pm 5 \\
69 \pm 8 \\
90 \pm 10\end{array}$ \\
\hline \multicolumn{5}{|l|}{ Hole 418A } \\
\hline $\begin{array}{l}28-1,21-25 \\
37-1,28-32 \\
40-1,82-85 \\
42-2,17-22 \\
69-4,26-29\end{array}$ & $\begin{array}{l}1.45 \pm 0.03 \\
1.40 \pm 0.03 \\
1.14 \pm 0.03 \\
1.05 \pm 0.03 \\
0.48 \pm 0.02\end{array}$ & $\begin{array}{r}6.2 \pm 0.4 \\
11.1 \pm 0.4 \\
6.9 \pm 0.4 \\
S .1 \pm 0.4 \\
3.1 \pm 0.2\end{array}$ & $\begin{array}{l}25: 38 \\
20: 51 \\
49: 51 \\
21: 25 \\
16: 23\end{array}$ & $\begin{aligned} 61 & \pm 4 \\
111 & \pm 6 \\
85 & \pm 6 \\
68 & \pm 5 \\
91 & \pm 10\end{aligned}$ \\
\hline
\end{tabular}

Note: Analysis by M. M. Arakeljanz.

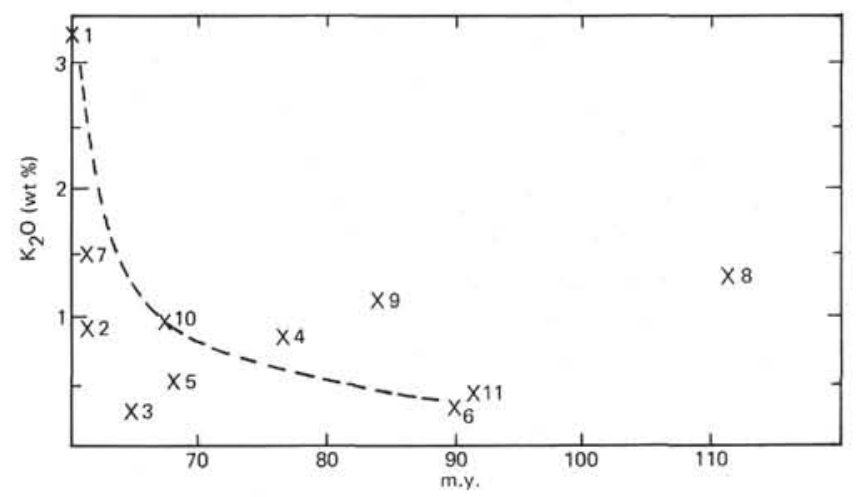

Figure 2. Relations between $\mathrm{K}$-Ar age and $\mathrm{K}_{2} \mathrm{O}$-content of altered basalts. Numbers correspond to those in Table 3. Other comments in the text.

exception of two samples. One basalt from Sample 417D22-4 (\#4) with a dated age of $111 \mathrm{~m} . \mathrm{y}$. has a glassy groundmass. The glass is replaced by palagonite, vesicles are filled with brown celadonite, and plagioclase phenocrysts are fresh. Therefore, most of the $\mathrm{K}_{2} \mathrm{O}$ is in palagonitelike smectite; thus the age of $111 \mathrm{~m} . \mathrm{y}$. is associated with this smectite. The estimated age ( $85 \mathrm{~m}$.y.B.P.) is greater for moderately altered basalt from Sample 418A-40-1, 82-85 $\mathrm{cm}$. Alteration of the basalt is accompanied by an increase in $\mathrm{K}_{2} \mathrm{O}$, but $\mathrm{K}$-feldspar is not formed. Secondary minerals are smectite with (or without) calcite and with a celadonite admixture. Two points on Figure 2, corresponding to the two described samples, deviate from the general tendency. In general, the more altered the basalt and the higher the $\mathrm{K}_{2} \mathrm{O}$ content, the "younger"' is the $\mathrm{K}-\mathrm{Ar}$ age. This tendency is shown in Figure 2 by the dotted line. The $\mathrm{K}_{2} \mathrm{O}$ content in fresh basalt varies within 0.10 to 0.40 per cent. In altered basalt, it is 0.5 to 3 weight per cent, and higher. All determined values correlate with the age of basalt weathering. 
Therefore, we propose that there were at least two stages of alteration: (1) close to the age of fresh basalts ( $\sim 90$ to 110 m.y.B.P.) when glass was palagonitized and partly replaced by smectites, mixed-layered mica-montmorillonites and calcite; and (2) younger ( $\sim 60$ m.y.B.P.), with the common formation of celadonite and with the replacement of plagioclase phenocrysts by K-feldspar. This is in accordance with the assumption of hydrothermal alteration for the basalts under study.

\section{ACKNOWLEDGMENTS}

The authors are grateful to V.A. Kovalenicer of the Institute of Ore Deposits, Geology, Petrography, Mineralogy, and Geochemistry, Academy of Sciences of the USSR, for his review of this paper.

\section{REFERENCE}

Ohmoto, H., 1968. Systematics of sulfur and carbon isotopes in hydrothermal ore deposits, Econ. Geol., v. 67, p. 551-578. 